\title{
Public-Private Partnership in the Prevention of Influenza Amongst Industry Workers in Ceara State
}

\author{
César Algusto Ribeiro ${ }^{1}$, Ana Vilma ${ }^{2}$, Karine Ana Borges Medeiros ${ }^{3}$, \\ Kassandra Maria de Araúo Morais ${ }^{4}$
}

\begin{abstract}
Influenza is an acute viral infection that affects the respiratory system, with high transmissibility and global distribution, with a tendency to easily spread in seasonal epidemics. Influenza vaccination is one of the most effective measures for the prevention of the disease and its complications. The flu was the main cause of absenteeism in 2015, affecting the productivity of companies and the economy in Brazil. However, it is a great challenge to grant access to vaccination for this audience that is not part of the government's priority group, the people withen it can not pay for vaccine in the private network thus generating absence at work to move to the vaccination posts. The occurrence of influenza among workers increases the cost for public health. In 2015 a public-private partnership between the State Health Secretariat and the Industry Social Service in Ceará was established, aiming to lead the national campaign of vaccination against influenza in industries, facilitating the access of workers to the vaccine without increasing the absence of these professionals in office hours. With the partnership, the vaccine within the industry facilitates access of workers and contributes to the improvement in health and reduction of the absenteeism related to flu.
\end{abstract}

Key Words: vaccine, partnership, absenteeism, industrial workers

\section{Introduction}

The Ministry of Health is an organ of the Federal Executive Branch responsible for the organization and elaboration of plans and public politics aimed to the promotion, prevention and assistance of the Brazilian's health.

According to the Ministry of Health, influenza is an acute viral infection that affects the respiratory system. This disease has a high transmission rate and global distribution, with a trend to spread easily in seasonal outbreaks and that may also develop into pandemics. The transmission occurs through respiratory secretion of the infected person when talking coughing, sneezing or through the hands, that, after contact with infected

${ }^{1}$ César Algusto Ribeiro CEO in Industry Social Service - SESI Ceará . Bachelor in Business Administration in the University Anhembi Morumbi. Master of Business Administration (MBA ) - Business Management in Ohio University. Master of Business Administration (MBA ) - Administration and Finance in Getulio Vargas / FGV.

${ }^{2}$ Ana Vilma - State Coordinator of immunization of the Government of the State of Ceará. Degree in nursing from the Federal University of Ceará and Pedagogic Education from the State University of Ceará. Public Health Specialist, Management Systems and Local Health.

${ }^{3}$ Karine Ana Borges Medeiros is a nurse, a specialist in Emergency and Emergency Technical Advisor in the National Immunization Program (NIP) of Ceará Health Department.

${ }_{4}^{4}$ Kassandra Maria de Araúo Morais Psychologist, consulting expert in business management and administration quality. Health and safety for the industry manager, the Social State of Ceará Industry Service. 
surfaces by respiratory secretions, may carry the infectious agent straight to the mouth, eyes and nose (BRAZIL, 2016).

With regards to the epidemiological characteristics, the influenza virus stands out among other emerging diseases, because it often suffers antigenic alterations. In Europe, Japan and United States, this virus affects more than 100 million people each winter. It is estimated that around $10 \%$ of the Global population is affected with one episode of the disease annually (FORLEO-NETO, 2003).

Fever, shivers, cough, headaches, sore throat, myalgia, fatigue and discomfort are the usual symptoms of influenza. Sometimes it also may cause diarrhea, vomit, hoarseness, conjunctival hyperemia, pneumonia and death, especially amongst children and the elderly. When the evolution is benign the clinical symptoms usually improve in 5 days after they start, however there are cases in which the affected person may take weeks to make a full recovery (Hisbello S Campos, Oswaldo Cruz Foundation).

According to Forleo-Neto et al., (2003) the influenza virus displays high mutation rates, that often result in the insertion of new viral variants in the community, to which the population has no immunity against. So, there are few available choices to control the disease. Thus, according to the previous author, Brasil (2016) describes that the vaccination against influence is shown as one of the most effective methods to prevent influenza and the serious complications derived from it.

Considering the information from the epidemiological surveillance agency, depending on the virulence of the circulation strains, it is possible that infections caused by more than one type of the virus occur in the same season.

Due to the constant changes in the antigenic and genomic characteristics that naturally occur to the influenza virus, it is recommended that the vaccination is done annually (FORLEO- NETO, 2003).

Based on the epidemiological data gathered around the world, a committee of experts meets at the World Health Organization (WHO) twice a year in order to formalize the recommendation of the influenza strains to be used in the production of the vaccine, so the most adequate vaccine for the next flu season is produced. The evaluations performed aim to pinpoint the geographical location, seasonality, incidence peak and extension of the flu activity, age groups and the characteristics of the circulation virus (FORLEO-NETO, 2003)

It is the ministry's role to have the conditions for the protection and recovery of the population's health, reducing disease, controlling endemic and parasitic diseases and improving health surveillance, thus giving a better quality of life to the Brazilian people.

\section{Discussion}

The public health structure in Brazil is composed by the States Health Secretariats. The Federal Constitution of 1988 was an important step in guaranteeing the right to health with the creation of the Unified Health System. Its principles point to democratization in health services, which are no longer restricted and become universal. With this decentralization, the states and municipalities assuming their responsibilities and prerogatives before the Unified Health System and develop activities to give priority to prevention and health promotion. 
In the National Vaccination Campaigns against influenza of the National Imunization Program, promoted by Ministry of Health, the vaccines are trivalent, in other words, they contain the antigens of both $\mathrm{A}$ and $\mathrm{B}$ strains, as determined by the WHO. According to Floreo-Neto et al., (2003), in Brazil the peak of the disease happens between May and September. So, the best time for the vaccination is in Aarch and April, reason why the National Vaccination Campaigns against the influenza take place in this period.

In 2016, it happened between April $30^{\text {th }}$ and May $20^{\text {th }}$.

Some individuals, like adults aged 60 or older, children under 5 years old, pregnant women, and people with non-transmittable disease and other especial chronic conditions, due to their high risk of infections and death, compose the priority groups that receive the vaccines available at the vaccination facilities of the Unified Health System.

In the other groups - and in several times in the group of people with comorbidities - the population in the working age, who usually has no access to the vaccination due to their work schedule as well as to the distance between their work places and the vaccination posts. These people, who often live or work in very crowded places, also present a high risk of getting infected by the virus, as the transmission rate of the virus in indoor environments is very high. Since the protection given by the vaccine lasts approximately one year, vaccination happens annually.

A research peformed by the Brazilian Institute of Geography and Statistics (IBGE, 2015), reported that respiratory infection was the main cause of absence at work, affecting the productivity of companies and consequently Brazil's economy. According to the epidemiological bulletin of the State Health Secretariat of Ceara, between January and May

2016, eight cases of Serious Acute Respiratory Syndrome (SARS) cause by influenza were confirmed in six counties of Ceara, and three of them, who did not possess any vaccination record evolved to death. The average age most affected by Influenza was 28 years old in

2015, and 31 in 2016.

Nichol et al.,(2007) based on other studies, has demonstrated that the vaccination was associated with a $27 \%$ decrease in the risk of hospitalization due to pneumonia or influenza and a $48 \%$ reduction in the risk of death. According to the assessment conducted in 2011, the vaccine against influenza presented a $67 \%$ efficiency rate. The population with the highest benefits was HIV positive adults between the ages of 18 and $55(76 \%)$ followed by healthy adults between the ages of 18 and $46(70 \%)$ and healthy children between the ages of 6 and

24 months $(66 \%)$.

The flu is responsible for financial costs associated to the diagnosis, treatment, medical care, and changes in the health system. Also causing socio economic consequences 
related to costs with transport, absenteeism and impairment of working capacity (Hisbello S Campos, Oswaldo Cruz Foundation).

With such scenario, the need of actions aimed to prevent the transmission of the virus among the worker population is observed, and it needs to be done by vaccination, however, making vaccination available to this population is a great challenge, due to its high price, unaffordable most times, charged by the private sector, or the long commute to the vaccination posts, causing workers to miss work.

In order to execute the National Vaccination Campaigns, State Health Secretariat receives from the Ministry of Health a specific amount of vaccine needed to meet 100\% of the target population needs (priority groups). In 2016, according to the data published by the PNI, this amount represented 177416 dosages, in which 1.620 .499 $(91,22 \%)$ were applied. In the last six years (2010-2016) the vaccination goal against influenza has been met. It is worth to mention that, according to the Ministry of Health, at leat $80 \%$ of the target population must be vaccinated against influenza. After the time established by the Ministry of Health the vaccine surplus that was not given to the priority groups, is made available to the general population.

The Social Service of Ceara Industry Chamber, legal private entity created by law 70 years ago and under the command of the National Confederation of Industry, annually conducts vaccination campaigns through the industry; However, such a service has its cost passed on to clients, which can restrict access to said service in many cases.

Having as a challenge to increase the industry's productivity and to promote the wellbeing of the worker, the Social Service of Industry Chamber offers solutions to Brazilian business industries by an integrated web that englobes activities of education, security and health in the work space and quality of life, that has a decisive role in strengthening the industrial sector and the sustainable development in Brazil

The health of the population is a shared interest between the Health Secretariats and the Social Service of Industry Chamber.

\section{Final Considerations}

Considering that the occurrence of influenza amongst workers is meaningfully increasing the costs with health care in the public system, since 2015 it was established a public-private partnership between SESA and the Social Service of Ceara Industry Chamber, aiming to take the vaccination against influenza campaign into the industries, thus facilitating the access of workers to the vaccines without increasing the absenteeism rate of these professionals.

This partnership is based on the search for the optimization of resources and on the guidance of a public that contributes to the spread of the virus to the public health care, and even if this population presents many cases of comorbidity, it does not have many chances to go to vaccination posts to get their shots.

With this partnership, the vaccine gesture is done within the industry and during the working hours, so the access and presence of employees tend to be higher, contributing to the improvement of health and the reduction of influenza related absenteeism. 


\section{References}

Brasil. Ministério da Saúde. Secretaria de Vigilância em Saúde. Departamento de Vigilância de Doenças Imunopreveníveis. Coordenação Geral do Programa Nacional de Imunização. Informe técnico da Campanha Nacional de Vacinação contra a Influenza CGPNI/DEVIT/SVS/MS. Brasília: Ministério da Saúde, 2016, 41p.

Brasil. Ministério da Saúde. Secretaria de Vigilância em Saúde. Departamento de Vigilância de Doenças Imunopreveníveis. Coordenação Geral do Programa Nacional de Imunização. Informe técnico da Campanha Nacional de Vacinação contra a Influenza CGPNI/DEVIT/SVS/MS. Brasília: Ministério da Saúde, 2015, 43p.

Brasil. Ministério da Saúde. Secretaria de Vigilância em Saúde. Departamento de Vigilância Epidemiológica. Guia de vigilância epidemiológica / Ministério da Saúde, Secretaria de Vigilância em Saúde, 7. ed. - Brasília : Ministério da Saúde, 2009.

Boletim epidemiológico SRAG - Influenza 06/05/2016. Núcleo de Vigilância epidemiológica. Secretaria da Saúde do estado do Ceará. Disponível em:

$<$ http://www.saude.ce.gov.br/index.php/boletins $>$.Acesso em: 18 mai.2016.

FORLEO-NETO, Eduardo et al.,; Influenza; Rev. Soc. Bras. Med. Trop.; Uberaba; v. 36; n.

2; p. 267-274; Abril 2003.

NICHIL KL, Nordin JD, Nelson DB, Mullooly JP, Hak E. Effectiveness of influenza vacine in the community-dwelling elderly. N Engl J Med. 2007; 357:1373-81.

Pesquisa nacional de saúde: 2013: acesso e utilização dos serviços de saúde, acidentes e violências : Brasil, grandes regiões e unidades da federação / IBGE, Coordenação de Trabalho e Rendimento. - Rio de Janeiro : IBGE, 2015. 100 p.

Sistema de informações do Disponível em: $\quad$ http://sipni.datasus.gov.br/si-pnieb/faces/relatorio/consolidado/coberturaVAcinalCampanhainfluenza.jsf.

Acesso em:18 mai. 2016. 